\title{
Impact of Leadership Traits on School Improvement of Secondary School Principals in
}

\author{
Azad Jammu and Kashmir \\ * Maria Noureen, PhD Scholar \\ ** Dr. Nazir Haider Shah, Assistant Professor (Corresponding Author) \\ *** Dr. Ziarab Mahmood, Assistant Professor
}

\begin{abstract}
The major purpose of the research was to examine the effects of leadership traits of secondary school principals on school improvement. A descriptive research method was used to conduct the study. All 2270 secondary school teachers and 317 principals of division Mirpur were the population of the study. A universal sampling technique was used for the selection of samples. A questionnaire was developed which was focused on the objectives of the study. The instrument was based on the effects of leadership traits on school improvement. The instrument was validated from two experts of the field and the reliability of the questionnaire was measured through Cronbach's alpha. The reliability of the instrument was found .823 which was excellent for using the tool. The researcher used mean and linear regression tests for the analysis of data. It was found that the leadership traits of secondary school principals had a positive effect on school improvement. Therefore, it is recommended that school principals are proposed to practice different leadership traits in their school management to enhance school improvement.
\end{abstract}

Keywords: Leadership Traits, Leadership Trait Model School Improvement, Secondary Schools Introduction

Any individual place in an institution/organization or society is called leadership and basically, it is a relationship between followers and leaders (Silva, 2014). This is a composition of different factors. Leadership is a process in which we can motivate and observe the abilities of individuals. The purpose of these activities is to achieve organizational goals (Judge \& Bono, 2000). Leadership is the process by which individuals motivate, motivate and guide the organization's employees to achieve their goals (Haq, 2011).

The important function of leadership is to support, evaluate, and develop the quality of teachers. Under the influence of effective leadership skills, individuals can adequately direct, direct, and control the functioning of institutions (Pont, Nusche \& Moorman, 2008). Educational leaders have sufficient capacity to adapt the instructional program to the local requirements of the teacher. Leaders take steps to promote teamwork among teachers and participate in teacher supervision, evaluation, and professional development. Teachers should be effectively trained and knowledgeable about how to meet the needs of their students. Therefore, an important goal of educational leaders is to support, evaluate, and promote the development of teacher quality (Muijs, 2011).

The characteristics of an individual are called leadership traits that lead to become a leader. To achieve the organizational goals, the ability of an individual or an institution is referred to as leadership. It is very important because the ultimate purpose of leadership is to achieve organizational goals. In this regard, the role of leaders is very important because they motivate, encourage, direct, and boost the morale of individuals (Pont, Nusche \& Moorman, 2008).

In the past few decades, researchers have studied a variety of different Personality traits related to management efficiency. The selection of traits and the labels used for them vary from

\footnotetext{
* Department of Education, Mohi-ud-Din Islamic University, Nerian Sharif, AJ\&K

Email: marianoureen56@gmail.com

** Department of Education, Mohi-ud-Din Islamic University, Nerian Sharif, AJ\&K

Email: nazirshah786@gmail.com

*** Department of Education, Mohi-ud-Din Islamic University, Nerian Sharif, AJ\&K

Email: ziarabmahmood@gmail.com
} 
research to study, but the result is that there is considerable consistency in different research methods (Yukl, 2006). In 1990, Bath published the results of a broad review of leadership trait research and presented a list of stable personality traits that were supported by several empirical research institutes until the late 1980s. Since then, Zaccaro et al. (2004) and Yukl (2006) summarize leadership-related leadership traits that have received leadership support since Bass (1990) (Polat, 2009).

When an independent country inherits the established education system, the secondary education problems of Azad Jammu and Kashmir can be discovered from the beginning of the country. This research attempts to analyze the causes and solutions of various problems in AJ\&K state secondary education to effectively promote the development of the school. School leaders, especially principals and female principals, play a key role in setting the direction and creating a positive school culture. Therefore, the researchers decided to measure the impact of leadership traits on the school improvement of Azad Jammu and Kashmir secondary school principals.

\section{Objectives of the Study}

1. To identify leadership traits of secondary school principals.

2. To measure the effect of leadership traits of secondary school principals on school improvement.

\section{Research Question}

1. What are the leadership traits of secondary school headteachers?

2. What are the effects of leadership traits of secondary school principals on school

\section{Delimitation} improvement?

This study was delimited to:

1. Azad Jummu\& Kashmir

2. Govt secondary schools of Mirpur Division

\section{Review of Literature}

\section{Leadership Traits}

In the past few decades, researchers have studied a variety of different Personality traits related to management efficiency. The selection of traits and the labels used for them vary from research to study, but the result is that there is considerable consistency in different research methods (Yukl, 2006). In 1990, Bath published the results of a broad review of leadership trait research and presented a list of stable personality traits that were supported by several empirical research institutes until the late 1980s. Since then, Zaccaro et al. (2004) and Yukl (2006) summarize leadership-related leadership traits that have received leadership support since Bass (1990) (Poling, 2009).

\section{Rudduck Traits leadership model}

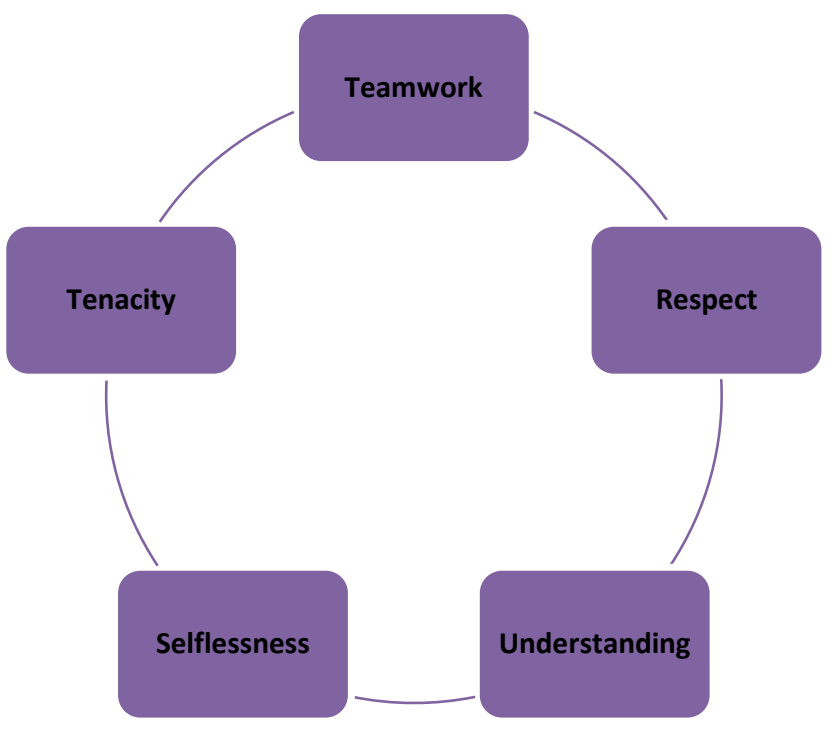

5 Traits of Educational Leadership by Ron Rudduck

Figure 1 Educational leadership trait model (2016) 
The current study focused on the leadership traits of secondary school principals. Therefore, the researcher choose Rudduck (2016) model of leadership traits. This model consisted of 5 elements like teamwork, respect understanding, selflessness, and tenacity. The detail of these elements are as under:

\section{Teamwork}

The team is an important part of today's successful organization construction, and motivating the team is a necessary pursuit for success. If a team wants to achieve success then it is mandatory to follow the characteristics such as build trust between leader and subordinates, joint tasks, achieve common goals, understand responsibilities, and free working environment. In this regard, Whetton \& Cameron (2011) are of the view that teamwork can be more effective and fruitful if there is developed formality between project and team members. This is further strengthened by teamwork sprit, team goals, cohesion among the teammates along with the decision making process with overall feedback.

A strong team recognizes that team members rely on each other to succeed, so they must work together to overcome adversity. This leads to realize that the stated goals can be better achieved by a strong and flexible team. it must also be considered that despite strong and flexible team success might be comprised of wrong leadership. Thus, a leader must be keen, capable, and prudent to introduce the teammates to new horizons of success. (Manteklow, 2011).

\section{Respect}

Leadership is very important for any organization as it affects the behavior and attitudes of the person as well as groups. Leadership is a method in which leaders and their subordinates achieve institutional goals (Lussier and Achua, 2001). To achieve the organizational goals leadership build relationship between leaders and their subordinates (DuBrin, 2012). Leadership is performing different roles that is why it is an art, on the other hand, leadership is doing practical work that is why it is a science. Furthermore, it is the composition of knowledge and skills that leads to achieving the organizational goals (Gill, 2012).

Leaders are born not manufactured, that is why a leader is born with special skills that lead to becoming a great leader. According to this statement, these special qualities and characteristics make a person different from a non-leader (Northhouse, 2013). Liker (2003) asserts that empowering employees will lead to a sense of fairness among employees and make them effective in organizational development. Rock (2009) notes that participatory systems also provide a chance for employees to speak and communicate their thought to make organizational decisions. Democratic leadership can enhance the job satisfaction of employees in any organization. Furthermore, employees' participation in the process of decision making can improve the performance and job satisfaction of employees (Luthans, 2002). Additionally, the relationship was found between job satisfaction and job input. It was also found that work commitments are directly proportional to job satisfaction (Brown, 2004); (Reddy and Sudneer, 2011).

\section{Understanding}

Leadership is a very popular topic over the decades, the organizations and employees are much interested to hear the news and innovative thoughts about how to become a good leader. Many workshops, seminars, research papers, and several books are being published in this regard. The development of individual personality, cognitive, social, and professional growth is possible in leadership (Northouse, 2010).

The assets of any organization is to bring changes in the minds of leaders and their subordinates. That is why the organizations a lot of budget to make and polish leaders in the organization. These directions may consume a heavy budget in the form of refresher courses offered by different universities. As a result of these courses, the leaders can polish themselves and learn different innovative skills and professional development. Furthermore, the organizations spend a lot of money on seminars and train their managers and executives for better leadership (Robbins \& Coulter, 2009).

\section{Selflessness}

Organizations can provide some kind of support to emerging leaders to promote their transition from selfishness to selflessness. For example, an in-house mentoring program is generally considered to be primarily beneficial to the mentee, and as the mentee's career develops, the mentoring program can be used to promote selflessness and encourage them to guide others. Today, organizations will need a lot of creativity and innovation to bridge the gap in the leadership development pipeline, making it easier to find the leaders that organizations need and desire. The benefits of doing so may include addressing 
some of the disengagement and dissatisfaction that employees often encounter in today's organizations. However, unfortunately, research shows that many employees prefer "main" leaders who are more concerned and empowered than focusing on goals (Pontefract, 2015). Although "no one wants a weak leader... selflessness is all about power, not for timid people... the real power is that we enable followers to achieve what they do, not by us. The pressure to measure the grip and the weight of our needs" (Kail, 2011).

Tenacity

For school leaders, resilience is closely related to the complexity of the role itself and the long-term challenges associated with the economic recession. A key element of leader tenacity is perseverance, or perseverance, and passion for the long-term (Deborah, 2016). Murnieks, Cardon, Sudek, and White (2016) report that enthusiasm can predict the adaptability of leaders and must be recognized and cultivated. Resilience reflects the perseverance of employees at work, especially when facing a challenging work environment (Bartram, 2005). More specifically, the adaptability of leaders is related to their thinking styles and skills. These ways of thinking and skills enable managers to shift their energy from short-term concerns to long-term or higher-level goals and to withstand challenges and setbacks. The ground is moving towards these goals. Apprentices whose intelligence, learning goals, higher goals, and awareness of the school district's culture continue to improve may show greater perseverance. Dweck (2006) claimed that people have been thinking rigidly. Those who think that ability is fixed - compared to those who have a constantly evolving way of thinking, are less likely to have this danger - those who think they can develop their skills through hard work, good strategies, and guidance people.

\section{School Improvement}

The focus of school improvement involvements is to build the ability of schools and teachers by speaking the numerous unified and symbiotic mechanisms of the education system to improve student performance (Hargreaves, Lieberman, Fullan \& Hopkins, 2007). Amongst other things, these content may comprise the curriculum of school, teaching practices, professional development prospects, and evaluation events (Supovitz, Sirinides, May, 2009). Exertions to progress one of the system components usually lead to changes in other mechanisms and changes in the entire system. In turn, this can help improve the abilities of schools and teachers and improve student academic performance (Hallinger \& Bryant, 2013).

The school improvement takes into account the local conditions of the education system recognizes that definite requirements, focus capacities, and improvement capabilities differ from school to school. So, effective systemic school improvement interventions are not focused on specific projects or narrowly defined interventions, but have different emphasis on school structure, process, and ability according to the needs of specific schools (Herman et al., 2008). This fit with the needs of individual schools is essential for promoting changes that will lead to the continued academic development of students (Fullan 2001; Holland \& Steward, 2000). According to Armandi, Oppedisano \& Sherman (2003), in a systematic approach to school improvement, school districts and schools organize and uniquely promote decisions to create, implement, and maintain basic school improvement work that is most relevant to their specific needs.

\section{Methodology}

The major purpose of the research was to examine the effects of leadership traits of secondary school principals on school improvement. A descriptive research method was used to conduct the study, in descriptive research survey method was applied for the collection of data. All secondary school teachers and headteachers of division Mirpur were the population of study. There were 2270 secondary school teachers and 317 headteachers working in secondary schools of Mirpur division. A universal sampling technique was used for this study. As the total number of respondents complete the requirement of this study, so the researcher used all populations for the sample of this study. A questionnaire was developed which was focused on the objectives of the study. The instrument was based on the effects of leadership traits on school improvement. Five-point Linkert Scale was used to collect the responses from the respondents. The instrument consisted of five main variables that also consisted of subscales of these variables. The instrument was validated by two experts who were belonged to the Department of Education, Mohi-Ud-Din Islamic University AJ\&K. The reliability of the questionnaire was measured through Cronbach's Alpha. The reliability of the instrument was found .823 which was excellent for using the tool. The questionnaires were administered personally to 
avoid ambiguities during data collection to assure the robustness and reliability of the information received. The researcher used statistical package for social sciences (SPSS) version 23 for the analysis of data. The researcher used mean and linear regression statistical tests for the analysis of data.

Analysis

Table 4.1 Mean score of principals' responses about sub-dimensions of Leadership Traits

\begin{tabular}{cc}
\hline Subscales & Mean \\
\hline Teamwork & 14.9697 \\
Respect & 14.2771 \\
Understanding & 14.5541 \\
Selfishness & 15.1169 \\
Tenacity & 15.2165 \\
\hline
\end{tabular}

Table 1 shows the mean score values of subdimensions of variables of leadership traits of principals. This table shows that the sub-dimension named Tenacity $(M=15.2165)$ has the highest mean value as compared to other dimensions.

Table 2 Mean scores of teachers responses regarding Sub Dimensions of Leadership Traits

\begin{tabular}{cc}
\hline Subscales & Mean \\
\hline Teamwork & 15.1933 \\
Respect & 15.0780 \\
Understanding & 15.2518 \\
Selfishness & 15.1064 \\
Tenacity & 15.1206 \\
\hline
\end{tabular}

Table 2 shows the mean score values of subdimensions of variables of leadership traits of teachers. This table shows that the sub-dimension named Understanding $(M=15.2518)$ has the highest mean value as compared to other dimensions.

Table $3 \quad$ Model summary of leadership traits of heads and school improvement

\begin{tabular}{ccccc}
\hline Model & $\mathrm{R}$ & R Square & Adjusted R Square & Std. Error of the Estimate \\
\hline 1 & $.648^{\mathrm{a}}$ & .420 & .417 & 2.146 \\
\hline
\end{tabular}

a. Predictors: (Constant), leadership traits total

Table 3 shows the model summary of leadership traits of heads and their effect on school improvement. According to the model summary, the value of correlation was $\mathrm{R}=.648$ and $\mathrm{R}^{2}=.420$. The table further indicated that there was a moderate positive relationship between leadership traits of heads and school improvement.

Table $4 \quad$ ANOVA summary of leadership traits of heads and school improvement

\begin{tabular}{ccccccc}
\hline Model & & Sum of Squares & Df & Mean Square & $\mathrm{f}$ & Sig. \\
\hline 1 & Regression & 763.084 & 1 & 763.084 & 165.584 & $.000^{\mathrm{a}}$ \\
& Residual & 1055.332 & 229 & 4.608 & & \\
& Total & 1818.416 & 230 & & & \\
\hline
\end{tabular}

a. Predictors: (Constant), leadership traits total

a. Dependent Variable: school improvement

Table 4 depicts the ANOVA summary of leadership traits of heads and their effect on school improvement. The table revealed that the regression equation was significant and $\mathrm{F}(1,229)=165.584$, $\mathrm{p}=.000$. Therefore, leadership traits of heads were a significant predictor to predict school improvement.

Table $5 \quad$ Coefficient summary of leadership traits of heads and school improvement

\begin{tabular}{|c|c|c|c|c|c|c|}
\hline \multirow[b]{2}{*}{ Model } & & \multicolumn{2}{|c|}{ Unstandardized Coefficients } & \multirow{2}{*}{$\begin{array}{c}\text { Standardized } \\
\text { Coefficients }\end{array}$} & \multirow[b]{2}{*}{$\mathrm{t}$} & \multirow[b]{2}{*}{ Sig. } \\
\hline & & B & Std. Error & & & \\
\hline \multirow[t]{2}{*}{1} & (Constant) & -1.274 & 1.293 & & -.986 & .325 \\
\hline & Leadership traits & .185 & .014 & .648 & 12.868 & .000 \\
\hline
\end{tabular}

a. Dependent Variable: school improvement

Table 5 shows the coefficient summary of leadership traits of heads and school improvement. The table showed that the value of the coefficient of leadership traits was .185 and its $t=12.868$ which 
was significant at the 0.5 level as $\mathrm{p}=.000$. It means that there was a significant difference between the leadership traits of heads and school improvement.

\section{Discussion}

The major purpose of this study was to measure the impact of Leadership Traits on School improvement of secondary school principals in Azad Jammu and Kashmir. The first objective of the study was to identify leadership traits of the principals of the secondary schools and their effect on the improvement of the standard of schools. All the principals responded to all the questions. It revealed that almost all the secondary school principals had different leadership traits. Leadership traits had very strong and positive effects on school improvement. Leadership traits remained on the top so according to the above results, principals leadership traits affect more on school improvement. Significant expressions of the personality traits of school principals may be linked to the findings of previous studies that suggest an association between personality traits and leadership (Crant \& Bateman, 2001; Judge \& Bono, 2000), especially in dynamic times (Polyhart et al.,2001) in contrast to the finding of De Hoogh et al (2005) who did not find this association.

To assess the leadership traits of principals it was found that there was a positive effect of leadership traits of principals on the school improvement. It is encouraging that the importance of the teamwork characteristics of teachers and principals among all the leadership abilities reported by participants is very high. For a long time, the literature has shown the positive benefits of teamwork (for example, Datnow, 2011; Ronfeldt, Farmer, McQueen \& Grissom, 2015; Shapira-Lischshinky \& Aziel, 2010; Tschida, Smith \& Fogarty, 2015; Vangrieken et al., 2015) Also supports teamwork.

\section{Conclusions}

1. It is concluded that tenacity leadership traits of principals is very dominated trait among the principals on the other hand secondary school teachers argued that understanding leadership trait is dominated trait among the principals.

2. It is concluded that there is a significant difference between the leadership traits of principals and school improvement. Therefore, the leadership traits of principals is a significant predictor to predict school improvement. Furthermore, the leadership traits of secondary school principals have a positive effect on school improvement.

\section{Recommendations}

1. Principals who are interested in creating or maintaining a strong and positive culture can exercise different leadership skills in the school. Leaders may be flexible and willing to use the style that best suits each situation. Besides, it is recommended that all school principals implement different leadership skills in school management to improve school standards.

2. The improvement of the school depends on the ability to improve, creating an environment that makes the morale of teachers (and students) high and encourages teachers to participate in the process of change. In all these areas, school leaders may play a key role. They provide guidance and set a vision, inspire a positive school culture, and act as mediators and motivators in the research process.

\section{References}

Armandi, B., Oppedisano, J. \& Sherman, H. (2003). Leadership theory and practice: a "case" in point, Management Decision, 41(10), 1076-1088.

Bartram, D. (2005). The great eight competencies: A criterion-centric approach to validation. Journal of Applied Psychology, 90(4), 1185-1203.

Bass, B. (1990). Handbook of leadership: Theory, research, and managerial applications, 3rd Edition. New York: The Free Press.

Brown, K. M. (2004). Leadership for social justice and equity: Weaving a transformative framework and pedagogy. Educational Administration Quarterly, 40(1), 77-108.

Crant, J. M., \& Bateman, T. S. (2000). Charismatic leadership viewed from above: the impact of proactive personality. Journal of Organizational Behaviour, 21(3), 63-75.

Datnow, A (2011). Collaboration and contrived collegiality: Revisiting Hargreaves in the age of accountability. Journal of Educational Change, 12(2), 147-158.

De Hoogh A. H. B., Den Hartog D. N., Koopman P. L. (2005). Linking the big five-factors of personality to charismatic and transactional leadership; perceived dynamic work environment as a moderator. Journal of Organizational Behaviour 26(2), 839-865. 
Deborah, M. N. (2016). Rethinking professional learning for teachers and school leaders, Journal of Professional Capital and Community, 1(4), 270-285.

DuBrin, A. J. (2012). Leadership: Research Findings, Practice, and Skills. Cengage Learning, 35(3), 267-269.

Dweck, C. S. (2006). Mindset: The new psychology of success. New York, NY: Random House.

Fullan, M. (2001). Leading in a culture of Change, Jossey Bass: San Francisco CA.

Gill, R. (2012). Theory and Practice of Leadership. Roger Call, 23(2), 171-172.

Hallinger, P., \& Bryant, D. (2013). Mapping the Terrain of Educational Leadership and Management in East Asia. Journal of Educational Administration, 51(5), 618-637.

Haq, S. (2011). Ethics and leadership skills in the public service. Procedia-Social and Behavioral Sciences, 15(1), 2792-2796.

Hargreaves, A., Lieberman, A., Fullan, M., \& Hopkins, D. (2007). The international handbook of educational change. Dordrecht: Kluwer.

Herman, R., Dawson, P., Dee, T., Greene, J., Maynard, R., Redding, S., \& Darwin, M. (2008). Turning around chronically low-performing schools: A practice guide. Washington, DC: National Center for Education Evaluation and Regional Assistance, Institute of Education Sciences, U.S.

Holland, L. \& Steward, T. (2000). A different divide: preparing tech-savvy leaders. Leadership, 30(1), 810-821.

Judge, T. A., Bono, J. E. (2000). Five-Factor Model of personality and transformational leadership. Journal of applied psychology, 85(3), 751-765.

Kail, E. (2011). Leadership character: The role of selflessness. The Washington Post Online https://www.washingtonpost.com/blogs/guestinsights/post/leadership-character-the role of selflessness /2011/04/04/gIQALaziTI_blog.html?noredirect=on\&utm_term=.83fcb6280ad1

Liker, J. (2003). The Toyota Way: 14 Management Principles from the World's Greatest Manufacturer (3Ed). London: McGraw Hill Professional.

Luthans, F. (2002). The need for and meaning of positive organizational behavior. Journal of Organizational Behavior, 23(4), 695 - 706.

Manteklow, J. (2011). Forming, storming, norming, and performing. Retrieved from: http://www.mindtools.com/pages/article/newLDR_86.htm

Muijs, D. (2011). Leadership and organizational performance: From research to prescription? International Journal of Educational Management, 25(1), 45-60.

Murnieks, C. Y., Cardon, M. S., Sudek, R., White, T. D., \& Brooks, W. T. (2016). The role of passion, tenacity, and inspirational leadership in angel investing. Journal of Business Venturing, 31(4), 468-484.

Northouse P. (2010), Leadership: Theory and Practice (5th ed.). Thousand Oaks, CA: Sage Publications.

Northouse, P. G. (2013). Leadership: theory and practice (3rd ed.). London, UK: Sage Publications.

Ployhart, R. E., Lim, B. C. \& Chan, K. Y. (2001). Exploring relations between typical and maximum performance ratings and the five-factor model of personality. Personnel Psychology, 54(4), $809-43$.

Polat, S. (2009). Organizational citizenship behavior (OCB) display levels of the teachers at secondary schools according to the perceptions of the school administrators. Procedia-Social and Behavioral Sciences, 1(1), 1591-1596.

Pont, B., Nusche, D. \& Moorman, H. (2008). Improving School Leadership. Retrieved December 18, 2017 fromhttps://www.oecd.org/edu/school/44374889.pdf

Pontefract, D. (2015). The collateral damage of selfish leadership. Forbes Online (January 5). https://www.forbes.com/sites/danpontefract/2015/01/05/thecollateral-damage-ofselfish-leader ship/\#568e78b44754.

Robbins S., Coulter M., (2009), Management (10 ${ }^{\text {th }}$ ed.). Upper Saddle River, NJ: Prentice-hall.

Rock, D. (2009). Managing with the brain in mind. Organization and people, 8(56), 27-28.

Ronfeldt, M., Farmer, S., Mcqueen, K., \& Grissom, J. (2015). Teacher collaboration in instructional teams and student achievement. American Educational Research Journal, 52(6), 475-514.

Shapira-Lischshinsky, O., \& Aziel, V. (2010). Team culture perceptions, commitment, and effectiveness: Teamwork effects. Educational Practice and Theory, 32(2), 33-56. 
Silva, A. (2014). What do we know about leadership? Journal of Business Studies Quarterly, 5(4), 14.

Sudheer, A. K. (2011). A study on Employee involvement and Job Satisfaction in Indian Corporate Sector. IJEMR, 1(6), 122-130.

Supovitz, J., Sirinides, P., \& May, H. (2009). How principals and peers influence teaching and learning. Educational Administration Quarterly, 46(1), 31-56.

Tschida, C. M., Smith, J. J., \& Fogarty, E. A (2015). "It just works better": Introducing the 2:1 model of co-teaching in teacher preparation. The Rural Educator, 36(3), 11-26.

Vangrieken, K., Dochy, F., Raes, E., \& Kyndt, E. (2015). Teacher collaboration: A systematic review. Educational Research Review, 15(1), 17-40.

Whetten, D. A. \& Cameron, K. S. (2011). Developing management skills. Upper Saddle River, NJ: Prentice-Hall/Pearson.

Yukl, G. (2006). Leadership in Organizations (6th ed.). Upper Saddle River, New

Zaccaro, S. J., Kemp, C., \& Bader, P. (2004). Leader Traits and Attributes: The Nature of Leadership. Thousand Oaks, CA: Sage Publications. 